\title{
Lama Waktu Inkubasi Terhadap Morfologi Bakteri Neisseria gonorrhoeae
}

\author{
Lu'lu'il Adawiyah ${ }^{1 *}$, Maruni Wiwin Diarti ${ }^{2}$, Erlin Yustin Tatontos ${ }^{3}$ \\ 1. Jurusan Analis Kesehatan, Poltekkes Kemenkes Mataram, Indonesia \\ 2. Jurusan Analis Kesehatan, Poltekkes Kemenkes Mataram, Indonesia \\ 3. Jurusan Analis Kesehatan, Poltekkes Kemenkes Mataram, Indonesia \\ *Email korespondensi : adawiyahyes@gmail.com
}

\begin{abstract}
Abstrak
Lama waktu yang digunakan untuk menginkubasi bakteri akan mempengaruhi pertumbuhan bakteri tersebut secara makroskopis dan mikroskopis. Biakan bakteri pada kondisi inkubasi yang lama atau diatas waktu optimum yang diperlukan oleh bakteri untuk tumbuh akan mempengaruhi morfologi bakteri secara mikroskopis, bentuk bakteri akan berbeda dari bentuk dasarnya sehingga tidak dapat diamati dengan jelas karena pengaruh lama waktu inkubasi yang digunakan. Penelitian ini bertujuan untuk mengetahui adanya pengaruh lama waktu inkubasi terhadap morfologi bakteri Neisseria gonorrhoeae, penelitian ini bersifat pre-eksperiment yang menggunakan biakan murni bakteri Neisseria gonorrhoeae (gram negatif) dengan waktu inkubasi 24, 48, 72, dan 96 jam. Hasil preparat bakteri Neisseria gonorrhoeae diperoleh bentuk mikroskopis bakteri coccus pada lama waktu inkubasi 24 dan 48 jam dengan kategori baik. Dari hasil penelitian dapat ditarik kesimpulan bahwa lama waktu inkubasi yang baik digunakan untuk mengamati morfologi bakteri Neisseria gonorrhoeae pada lama waktu inkubasi 24 dan 48 jam.
\end{abstract}

Kata kunci: Morfologi Bakteri, Neisseria Gonorrhoeae, Waktu Inkubasi

Abstract

The incubation time used to incubate bacteria will affect the growth of the bacteria macroscopically and microscopically. Culture of bacteria in incubation conditions that are long or above the optimum time needed by bacterial morphology macroscopically, the shape of the bacteria will be different from the basic form so that it cannot be clearly observed due to the influence of the incubation time used. This study aimed to determine the effect of incubation time on the morphology of Neisseria gonorrhoeae bacteria, this study was pre-experimental using pure cultures of Neisseria gonorrhoeae (Gram negative) with incubation times of $24,48,72$ and 96 hours. The result of Neisseria gonorrhoeae bacterial preparations obtained by microscopic form of the coccus at the incubation time of 24 and 48 hours in good category. From the result of the study it can be concluded that a good incubation time is used to observe the morphology of Neisseria gonorrhoeae bacteria at incubation time of 24 and 48 hours.

Keywords: Bacterial morphology, Incubation time, Neisseria gonorrhoeae

\section{PENDAHULUAN}

Penyakit infeksi menular seksual (IMS) merupakan salah satu dari sepuluh penyebab pertama penyakit dewasa muda laki-laki dan penyebab kedua terbesar pada dewasa muda perempuan di negara berkembang. Dewasa dan remaja (15-24 tahun) merupakan 25\% dari semua populasi yang aktif secara seksual, tetapi memberikan konstribusi hampir $50 \%$ dari semua kasus IMS baru yang didapat. Kasus kasus IMS yang terdeteksi hanya menggambarkan 50\%-80\% dari semua kasus 
IMS yang muncul mencerminkan keterbatasan "screening" dan rendahnya pemberitaan akan IMS (Arjani, 2015).

Gonore disebabkan oleh bakteri Neisseria gonorrhoeae.Neisseria gonorrhoeae yaitu bakteri kedua yang paling umum dapat menyebabkan infeksi menular seksual.World Health Organization (WHO) memperkirakan bahwa pada tahun 2012, didapatkan 78 juta kasus baru terjadi di kalangan remaja dan dewasaberusia 15-49 tahun di seluruh dunia. Spesimen dari semua kasus yang diduga infeksi gonokokus harus dikumpulkan untuk kultur mikrobiologis dan pengujian kerentanan antimikroba (WHO, 2016).

Berdasarkan data dari Kementerian Kesehatan RI, kasus IMS pada tahun 2016 dari bulan Januari sampai dengan Desember 2016 jumlah kasus Duh Tubuh Uretra (DTU) dilaporkan sebanyak 10.672 kasus, dan kasus luka pada alat kelamin / Ulkus Genital dilaporkan sebanyak 1.628 kasus di Indonesia (Kemenkes RI, 2017).Infeksi gonore di Indonesia pada tahun 2011 menempati urutan yang tertinggi dari semua jenis penyakit menular. Beberapa penelitian di Surabaya, Jakarta dan Bandung pada wanita pekerja seks menunjukkan bahwa prevalensi gonore berkisar antara 7,4\%-50\%. Salah satu penyebab penyakit gonore (GO) ini adalah bakteri Neisseria gonorrhoeae, suatu diplokokus Gram negatif berbentuk diplokokus.

Spesies Neisseria adalah bakteri gram negatif aerob, berbentuk diplokokus (berdiameter 0,6 hingga $1,0 \mu \mathrm{m}$ ) dan berpasangan (diplococcus) dengan sisi yang berdekatan (menyerupai biji kopi). Semua spesies menghasilkan oksidase positif dan sebagian besar menghasilkan katalase, sifat itu dikombinasikan dengan hasil morfologi pewarnaan Gram yang lebih efektif dan efisien (Murray, Rosenthal, \& Michael A. Pfaller, 2016).

Neisseria gonorhoeae diidentifikasi dengan pewarnaan Gram dan didapatkan bakteri diplokokus berbentuk seperti biji kopi dan sifat Gram negatif.Bakteri Gram negatif mempunyai lapisan peptidoglikan yang tipis, hanya 1-2 lapisan dan susunan dinding selnya tidak kompak, permeabilitas dinding sel lebih besar. Isolasi pada bakteri Neisseria gonorhoeae dapat menggunakan waktu yang optimal dalam 48 jam pada suhu $37^{\circ} \mathrm{C}$ menggunakan media diperkaya sehingga didapatkan morfologi bakteri seperti membentuk koloni konveks, mengkilat, meninggi, mukoid dengan diameter 1-5 mm. koloni bersifat transparan dan opak, tidak berpigmen dan tidak hemolitik (Brooks, Carrol, Butel, Morse, \& Mietzner, 2012).

Kultur bakteri untuk Neisseria gonorrhoeae memiliki spesifisitas lebih dari 99\%, sensitivitas kultur untuk Neisseria gonorrhoeae berkisar antara 50\% hingga 92\% dikurangi dengan waktu transpor yang kurang optimal (yaitu melebihi 24 hingga 48 jam). Kultur dapat digunakan sebagai isolat untuk pengujian kerentanan antimikroba, penting untuk terapi antibiotik yang ditargetkan (misalnya kultur sebagai tes penyembuhan yang dilakukan untuk dugaan kegagalan pengobatan) dan untuk pengawasan terhadap resistensi Neisseria gonorrhoeae(Guerra et al., 2018).Sampel dikultur pada media transport growth sebelum pengiriman ke laboratorium. Dengan hasil oksidase-positif, diplokokus Gram-negatif didapatkan dari $100 \%$ kultur sampel yang dikirim dalam satu hari, $67 \%$ setelah 2 hari, dan $17 \%$ setelah 3 hari. Koloni tetap menghasilkan oksidase-positif bahkan setelah 3 hari, tetapi terdapat gonokokus yang autolysis pada pewarnaan gram (Kraus, 2009).

Isolasi mikroba khususnya bakteri Neisseria gonorrhoeae biasanya menggunakan waktu inkubasi yaitu 48 jam, bila terjadi variasi waktu inkubasi lebih pendek atau lebih panjang dari 48 jam apakah akan mempengaruhi secara kualitatif terhadap morfologi bakteri Neisseria gonorrhoeae sebelumnya belum pernah dilaporkan, sehingga perlu dilakukan penelitian mengenai "Pengaruh Lama Waktu Inkubasi Terhadap Morfologi Bakteri Neisseria gonorrhoeae“.

\section{METODE}

Penelitian ini bersifat pre experiment yang dilakukan di laboratorium untuk mengetahui suatu gejala atau pengaruh yang timbul sebagai akibat dari adanya perlakuan terhadap sampel.Penelitian dilakukan di Laboratorium Mikrobiologi Politeknik Kesehatan Mataram Kementerian Kesehatan RI pada bulan Februari sampai Juni 2019.Unit 
eksperiment dalam penelitian ini adalah bakteri Neisseria gonorrhoeae.

Variabel bebas dalam penelitian ini adalah lama waktu inkubasi ( 24 jam, 48 jam, dan 72 jam ).Variabel terikat yang merupakan variabel yang diukur yaitu morfologi bakteri Neisseria gonorrhoeae.Data dari variable independent berupa lama waktu inkubasi yang dikategorikan dalam variasi lama waktu inkubasi dengan jenis data primer, skala datanya ordinal.Data dari variable dependent yaitu morfologi dari bakteri Neisseria gonorrhoeaedengan jenis data primer, skala datanya nominal.

Teknik pengambilan unit eksperiment menggunakan purposive sampling. Adapun karakteristik unit eksperiment yang digunakan adalah :kultur murni bakteri Neisseria gonorrhoeae dengan hasil kultur menunjukkan morfologi Neisseria gonorrhoeae pada pemeriksaan pengecatan Gram dan tidak kontaminan. Data berupa hasil pengamatan yang diperoleh untuk mengetahui adanya pengaruh terhadap perlakuan masing-masing variabel dianalisis secara statistik, analisis data yang digunakan untuk mengetahui pengaruh lama inkubasi terhadap morfologi bakteri Neisseria gonorrhoeae adalah uji chi-square, dengan taraf kesalahan 5\% menunjukkan tidak terdapat hubungan antar variabel.

\section{HASIL}

Tabel 4.1 Hasil pengamatan preparat bakteri Neisseria gonorrhoeae menggunakan lama waktu inkubasi 24, 48, 72, 96 jam.

\begin{tabular}{|c|c|c|c|c|}
\hline \multirow{2}{*}{$\begin{array}{c}\text { Kode } \\
\text { Replikasi }\end{array}$} & \multicolumn{4}{|c|}{ Morfologi Bakteri Neisseria gonorrhoeae (Setiap Perlakuan) } \\
\cline { 2 - 5 } & T1 & T2 & T3 & T4 \\
\cline { 2 - 5 } & 24 jam & 48 jam & 72 jam & 96 jam \\
\hline R1 & Baik & Baik & Baik & Tidak baik \\
\hline R2 & Baik & Baik & Tidak Baik & Tidak baik \\
\hline R3 & Baik & Baik & Tidak Baik & Tidak baik \\
\hline R4 & Baik & Baik & Tidak baik & Tidak baik \\
\hline R5 & Baik & Baik & Tidak baik & Tidak baik \\
\hline R6 & Baik & Baik & Tidak baik & Tidak baik \\
\hline
\end{tabular}

Tabel 4.1 diatas terlihat bahwa morfologi bakteri diamati pada preparat bakteri Neisseria gonorrhoeae yang dicat menggunakan cat Gram dengan masing-masing lama waktu inkubasi 24, 48, 72, dan 96 jam didapatkan dihasilkan pewarnaan yang dapat mewarnai badan bakteri dengan kualitas pewarnaan sesuai dengan jenis golongan Gram negatif. Dengan morfologi bakteri yang baik (bentuk diplococus) adalah lama waktu inkubasi 24 dan 48 jam; morfologi bakteri dengan kategori tidak baik (bentuk bakteri lisis) adalah lama waktu inkubasi 72 dan 96 jam.

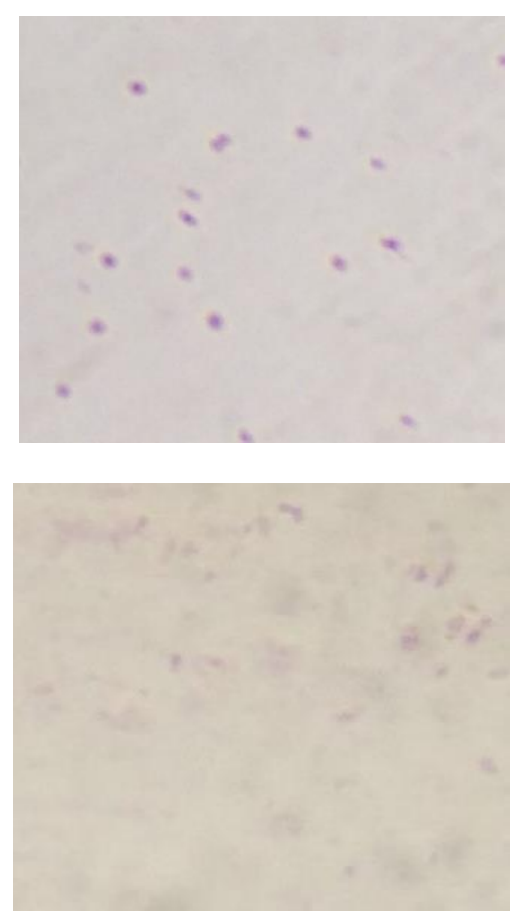

Gambar 4.1 Morfologi bakteri Neisseria gonorrhoeae pada lama waktu inkubasi selama 72 jam

Morfologi bakteri Neisseria gonorrhoeae setelah diinkubasi selama 72 jam kemudian dilakukan pengamatan mikroskopis dengan pengecatan Gram didapatkan bakteri Neisseria gonorrhoeae sifat Gram negatif dengan bentuk bakteri yang sudah lisis.Morfologi bakteri Neisseria gonorrhoeae setelah diinkubasi selama 96 jam kemudian dilakukan pengamatan mikroskopis dengan pengecatan Gram didapatkan bakteri Neisseria gonorrhoeae dengan bentuk bakteri yang sudah lisis.

Tabel 4.2 Hasil uji Chi-square pengamatan Neisseria gonorrhoeae menggunakan lama waktu inkubasi 24, 48, 72, 96 jam.

\begin{tabular}{|l|c|c|}
\hline \multirow{2}{*}{ Chi square } & $\mathrm{df}$ & Sig. \\
\cline { 2 - 3 } & 3 & 0,000 \\
\hline
\end{tabular}


Berdasarkan tabel diatas diketahui nilai Asympt.Sig. (2-sided) pada uji Pearson ChiSquare adalah sebesar 0.000.Karena nilai Asympt.Sig. (2-sided) $0.000<0.05$, maka berdasarkan dasar pengambilan keputusan diatas, dapat disimpulkan bahwa lama waktu inkubasi dapat mempengaruhi morfologi bakteri Neisseria gonorrhoeae.

\section{PEMBAHASAN}

Preparat bakteri yang diwarnai dengan safranin diperoleh kualitas yang baik karena menurut (Pelczar, 2009), bakteri Gram negatif memiliki dinding sel yang lebih tipis (10-15 nm) dan persentase lemak lebih tinggi (1124\%) daripada Gram positif dikarenakan bakteri Gram negatif memiliki peptidoglikan sedikit yang mampu menyerap warna merah hingga yang muncul pada pengamatan mikroskopis terlihat kontras. Pada pewarnaan masing-masing waktu inkubasi didapatkan hasil pewarnaan dengan kualitas baik ada 2 waktu inkubasi yaitu 12 dan 24 jam, sedangkan hasil pewarnaan Gram menggunakan waktu inkubasi 48 dan 72 jam menghasilkan pewarnaan dengan kualitas yang kurang baik dan hasil pewarnaan Gram menggunakan waktu inkubasi 96 jam menghasilkan pewarnaan yang tidak baik (Widnyana, 2018).

Pada masing-masing lama waktu inkubasi bakteri Neisseria gonorrhoeae didapat warna merah dengan bentuk morfologi yang baik (diplococcus) namun pada lama waktu inkubasi 72 dan 96 jam sudah tidak dapat diamati dengan baik karena morfologi dan penyerapan pewarna safranin oleh bakteri tersebut sudah tidak baik, karena lama waktu inkubasi yang sudah tua, kurangnya kandungan nutrisi pada media yang menyebabkan mikroorganisme yang tumbuh tidak dapat beregenerasi dengan baik dan memberikan pengaruh pada dinding sel bakteri untuk menyerap cat Gram.

Waktu penyimpanan kultur akan mempengaruhi pada kemampuan dinding sel bakteri untuk menyerap warna utama (crystal violet) dan warna penutup (safranin). Pada kondisi umur kultur tua dinding sel bakteri tidak dapat menyerap zat warna dengan baik karena kebutuhan nutrisi pada bakteri yang terdapat didalam media yang menyebabkan dinding sel bakteri mengalami masalah dalam menyerap zat warna dengan baik (Kawuri, Ramona, \& Darmayasa, 2007).

Berdasarkan penelitian yang telah dilakukan maka diperoleh kesimpulan bahwa morfologi bakteri Neisseria gonorrhoeae dengan lama waktu inkubasi 24 jam didapatkan bakteri berbentuk diplococcus sifat gram negatif dengan kategori baik, morfologi bakteri Neisseria gonorrhoeae dengan lama waktu inkubasi 48 jam didapatkan bakteri berbentuk diplococcus sifat gram negatif dengan kategori baik, morfologi bakteri Neisseria gonorrhoeae dengan lama waktu inkubasi 72 jam didapatkan bakteri dengan bentuk sudah lisis dengan kategori tidak baik, morfologi bakteri Neisseria gonorrhoeae dengan lama waktu inkubasi 96 jam didapatkan morfologi bakteri dengan bentuk sudah lisis dengan kategori tidak baik, lama waktu inkubasi yang baik digunakan untuk mengamati morfologi bakteri Neisseria gonorrhoeae dengan bentuk yang jelas secara mikroskopis yaitu pada lama waktu inkubasi 24 dan 48 jam. Berdasarkan kesimpulan dari penelitian ini, maka perlu disarankan melakukan kultur bakteri sebaiknya menggunakan lama waktu inkubasi 24-48 jam untuk jenis bakteri Neisseria gonorrhoeae dan diharapkan hasil penelitian ini dapat digunakan sebagai bahan tambahan ilmu pengetahuan dan wawasan bagi peneliti tentang pengaruh lama waktu inkubasi terhadap morfologi bakteri Neisseria gonorrhoeae.

\section{SIMPULAN}

Bahwa lama waktu inkubasi yang baik digunakan untuk mengamati morfologi bakteri Neisseria gonorrhoeae pada lama waktu inkubasi 24 dan 48 jam.

\section{SARAN}

Diperlukan penelitian lebih lanjut mengenai berbagai alternatif cara lain untuk mengoptimalkan pengamatan morfologi bakteri Neisseria gonorrhoeae

\section{UCAPAN TERIMA KASIH}

Terima kasih kepada pembimbing dan seluruh dosen di jurusan Analis Kesehatan yang telah banyak membantu dalam penyelesaian penelitian ini.

\section{DAFTAR PUSTAKA}


Arjani, I. A. M. S. (2015). Identifikasi Agen Penyebab Infeksi Menular Seksual. Skala Husada, 12 Nomor 1, 15-21.

Aryal, S. (2017). Biochemical Test and Identification of Neisseria gonorrhoeae.

Boleng, D. T. (2017). Bakteriologi: Konsep Konsep Dasar (Kedua). Malang: Universitas Muhamadiyah Malang.

Brooks, G., Carrol, K., Butel, J., Morse, S., \& Mietzner, T. (2012). Jawetz, Melnick \& Adelberg's Medical Microbiology 25th Edition. (A. Adityaputri.) (Ed 25). Jakarta: Peneribit Buku Kedokteran EGC.

Carrol, K. C., Butel, J. S., Morse, S. A., \& Mietzner, T. (2016). Jawetz, Melnick \& Adelberg's Medical Microbiology 27th Edition (27th Edition). United States: McGraw-Hill Education.

Fifendy, M. (2017). Mikrobiologi (Pertama). Depok: Kencana, Prenadamedia Group.

FKUB. (2003). Bakteriologi Medik. Malang: Banyumedis.

Guerra, F., Yu, Y., Macdonald, L., Menon, S., Pritchard, J., Whelan, M., \& Allen, V. (2018). Ontario Gonorrhea Testing and Treatment Guide, 2 nd Edition Guide. Toronto. Retrieved from https://www.publichealthontario.ca/en/eRe pository/guide-gonorrhea-testingtreatment.pdf

Idrus, I. (2017). Team Based Learning : Modul Gonore. Makasar: Fakultas Kedokteran Universitas Hasanuddin Makasar.

Kawuri, R., Ramona, Y., \& Darmayasa, I. B. G. (2007). Buku Ajar Mikrobiologi Farmasi. Jurusan Biologi F. MIPA UNUD : Bukit Jimbaran.

Kemenkes RI. Laporan Perkembangan HIVAIDS \& Penyakit Infeksi Menular Seksual (PIMS) Triwulan IV Tahun 2016 (2017).
Kraus, S. J. (2009). Culture Methods for Neisseria gonorrhoea. Journal of Reproductive Systems, Vol 3, hlm 343349.

https://doi.org/10.3109/014850179089884 26.

Meganada Hiaranya Putri, Sukini, Y. (2017). Bahan Ajar Keperawatan Gigi: Mikrobiologi (Pertama). Kementerian Kesehatan Republik Indonesia.

Murray, P. R., Rosenthal, K. S., \& Michael A. Pfaller. (2016). Medical Microbiology (8th Edition). Canada: Elsevier Inc.

Notoatmodjo, S. (2010). Metodologi Penelitian Kesehatan (xix). Jakarta: Rineka Cipta.

Octiara, D. L., \& Ungu, B. (2018). Electrochemical Biosensor Sebagai Diagnostik Terbaru Terhadap Penyakit Gonore, 7, 255-260.

Padoli. (2016). Modul Bahan Ajar Cetak Keperawatan: Mikrobiologi dan Parasitologi Kedokteran. (I. Winarni). Jakarta Selatan: Pusdik SDM Kesehatan Badan Pengembangan dan Pemberdayaan Sumber Daya Manusia Kesehatan.

Pelczar, M. J. \& C. (2009). Dasar-Dasar Mikrobiologi. Jakarta: UI Press.

Purnawati, A., Wuryandari, Y., Suryaminarsih, P., Wiyatiningsih, S., Nirwanto, H., \& Mujoko, T. (2017). Petunjuk Praktikum Mikrobiologi. Jawa Timur: Fakultas Pertanian Universitas Pembangunan Nasional "Veteran."

Smith, A., \& Baker, M. (1997). Cefsulodin Chocolate Blood Agar : A Selective Medium For The Recorvery of Haemophilus influenzae From The Respiratory Secretions of Patients With Cystic Fibrosis. J. Med. Microbiol, 46, 883-885.

Triastuti, L. E., \& Hadi, P. (2017). Uji Beda Sensitivitas Bakteri Neisseria gonorrhoeae 
Terhadap Levofloksasin Dan Kanamisin Secara In Vitro, 6(2), 782-790.

Ulfah, Liliek Harianie, Nur Kusmiyati, P. D. F. (2018). Buku Petunjuk Praktikum Mikrobiologi Umum. Malang: Jurusan Biologi Fakultas Sains Dan Teknologi Universitas Islam Negeri (UIN) Maulana Malik Ibrahim Malang.

WHO. (2016). WHO Guidelines For The Treatment of Neisseria gonorrhoeae. Switzerland. Retrieved from http://apps.who.int/iris/bitstream/10665/24 6114/1/9789241549691-eng.pdf

Widodo, D. L. U. (2016). Modul 1: Dasardasar Praktikum Mikrobiologi (hlm. 161). 